\title{
Methodical Approach to Activation of Technical and Technological Component of Enterprise Innovation in the Conditions of Digital Transformation of Socio-Economic Systems
}

\author{
Plakhotnik O. Olena, Korenyuk I. Petro, Serhieieva V. Natalia, Juliia G. Gavryluk
}

\begin{abstract}
The main focus in the development of socio-economic formations, and in particular industrial production, is shifted to the use of fundamentally new progressive technologies (built on the principles of the active use of environmentally friendly materials, safe ways of disposing of production and human wastes, non-waste production, material and energy efficiency and etc.), modern outputs with new consumer properties.
\end{abstract}

The need to accelerating the processes of digitalization and digital transformation of the economy is proved in order to achieve competitive positions in the emerging digital space of the new world economy.

At the theoretical and methodological level, it has been proved that the development and implementation of mechanisms for controlling the technical and technological component of innovation in the context of the digital transformation of socio-economic systems will contribute to increasing the strategic potential of subjects of the real sector of the economy, increasing their adaptive capabilities and strengthening competitive advantages.

In the new economic conditions, all domestic economic entities aiming at stable functioning are forced to go through the process of digital transformation, which is understood as the introduction of modern technologies into the business processes of socio-economic systems at all levels. It implies not only the installation of modern equipment or software, but also fundamental changes in approaches to management, corporate culture, and external communications. As a result, the profitability and business activity of the enterprise increase and it gains a reputation as a progressive and modern organization.

Digitalization issues for the innovative development of Ukrainian industry are the number one priority. They find a place in specifying the development strategies of the leading sectors of the national economy, especially export-oriented ones. They provide the flow of processes based on digital technologies. More and more digital products are emerging that provide digital, computing, telecommunications, and networking devices. At the same time, the digital economy is increasingly seen as a set of social relations that are formed as a result of the use of electronic technologies, as well as technologies to ensure the analysis of

Revised Version Manuscript Received on October 15, 2019.

Plakhotnik O. Olena, Doctor of Economic Sciences, Professor, Head of Department Department of Economy and Organization of Production Dniprovsk State Technical University, Ukraine

Korenyuk I. Petro, Doctor of Economics, Professor, Head of the Department of Management of Organizations and Administration of Dniprovsk State Technical University, Ukraine (Email: korenyukp@gmail.com)

Serhieieva V. Natalia, Head of scientific and organization department National scientific centre «Institute of agricultural engineering and electrification, Ukraine (Email: natushka1988@gmail.com)

Juliia G. Gavryluk, PhD student of National University of Life and Environmental Science, Kyiv, Ukraine large volumes of information to optimize the processes of forecasting, planning, output and consumption of science intensive and high-tech products, as well as increasing the level of economic development of the country.

The systematization of scientific work in the field of studying the factors influencing the innovative activity of an enterprise made it possible to develop the following classification of factors influencing the effectiveness of innovative processes, as well as to justify groups of factors (barriers) that impede the development and implementation of technological innovations in the context of structural changes in the global economy caused by its digitalization.

A very important stage in the development of relevant indicators is the formation of the information area on which they are defined. First of all, it is about the content of the initial indicators and their indicators, which are able to assess the effectiveness of the implementation of technical and technological innovations in enterprises of the real sector of the economy, while they should be objective characteristics of the relevant influence factors and can be obtained on the basis of official statistical information. The definition of the integrated performance index for the introduction of technical and technological innovations in enterprises of the real sector of the economy in the context of structural changes in the world economy caused by its digitalization and the corresponding sub-indices in its structure is based on a four-level hierarchical model, i.e., the integrated performance indicator is a vector with the types of sub-indices components on influence factors.

The developed hierarchical model allows us to build several types of sub-indices, differentially by hierarchy levels, for a deeper analysis of the current level of effectiveness of the introduction of technical and technological innovations in enterprises of the real sector of the economy in the context of structural changes in the world economy caused by its digitalization.

This approach provides an opportunity to accurately determine the main factors (and the degree of their impact) that affect the effectiveness of the introduction of technical and technological innovations in enterprises of the real sector of the economy in the context of structural changes in the world economy caused by its digitalization and justify management decisions in the structure of the corresponding management mechanism.

The practical implementation of the methodology for assessing the effectiveness of the innovative economy activating in the context of structural changes in the world economy caused by its digitalization is based on statistical data on the value of the relevant indicators (financial, economic, socio-economic, technical, technological, institutional and legal factors) for a certain period of time. This involves the use of official materials of the State Statistics Service of Ukraine, namely: structural statistics 
indicators for business entities, indicators of cost, availability and condition of fixed assets of enterprises of Ukraine by type of economic activity, capital investment by type and source of formation, indices of industrial products produced and sold and other technical and economic indicators of industrial enterprises.

As the main directions of enhancing and development of technical and technological innovations of enterprises in the real sector of the economy in the context of structural changes in the world economy caused by its digitalization we should consider: effective state support of innovative programs for the development of production enterprises (especially export-oriented), attraction of venture capital, increasing the financial stability of the enterprise, increasing the flexibility of production processes, the use of advanced methods of organizing production, labor and enterprise management.

Keywords: digitalization processes, innovative development, model, technical and technological innovations, factors, digital transformation of economy, digital technology, competitive ability.

\section{INTRODUCTION}

The transition of the domestic economy to an effective management system that meets modern scientific technical and technological conditions and the objective needs of world civilization, is possible only with the mastering of innovative development way. It is characterized by the fact that the main focus in the development of socio-economic formations, and in particular industrial production, is shifted to the use of fundamentally new progressive technologies (built on the principles of the active use of environmentally friendly materials, safe ways of production and human wastes disposing, non-waste production, material and energy efficiency, etc.), up-to-date output with new consumer properties.

To date, the national economy is characterized by a significant lag behind in the implementation of modern management and production technologies, updating the material and technical base, improving marketing techniques for products and managing business entities in comparison with the countries of the world. So, in Ukraine the number of enterprises with international quality certificates is $13.01 \%$ (in Europe over 22\%), the proportion of enterprises with annual financial statements confirmed by external auditors is $27.2 \%$ (in Europe over 53\%), the share of enterprises using licenses for technology of foreign companies - $26.6 \%$ (in Europe $-30 \%$ ). As a result of the technological lag behind, domestic metallurgical enterprises will not receive more than $24 \%$ of annual profit, fuel and energy complex - $18 \%$, transport - $12 \%$, agricultural sector - $11 \%$, which once again confirms the relevance of introducing technical and technological innovations to Ukrainian enterprises.

Leading economical scientists, practitioners recognized the need to accelerate the digitalization processes of economy digital transformation in order to achieve competitive positions in the emerging digital space of the new world economy,

The development and implementation of management mechanisms for the technical and technological component of innovation in the context of the digital transformation of socio-economic systems will contribute to increasing the strategic potential of entities in the real sector of the economy, their adaptive capabilities intensification and strengthening competitive advantages.
There are a number of unresolved issues regarding the directions of intensifying the technical and technological component of enterprise innovation in the context of financial resources shortage, identifying factors constraining the effectiveness of the technical and technological component of innovative activity in the digital transformation management of socio-economic systems, leading to the choice of this article topic.

The purpose of the study is to develop a hierarchical economic and mathematical model for determining the integral index of the effectiveness of the introduction of technical and technological innovations in the enterprises of the real economy sector, based on the proposed systematization of the factors hindering the successful implementation of innovations in a crisis state of the national economy in the context of structural changes in the world economy caused by its digitalization.

In the new economic conditions, all domestic economic entities aiming at stable functioning are forced to go through the process of digital transformation, which is understood as the introduction of modern technologies into the business processes of socio-economic systems at all levels. It implies not only the installation of modern equipment or software, but also fundamental changes in approaches to management, corporate culture, and external communications. As a result, the profitability and business activity of the enterprise increase and it gains a reputation as a progressive and modern organization. In practice, this means creating a system of end-to-end business processes, which can be called a digital ecosystem of business [1]. Thus, the digital economy, replacing the market economy, forms a new socio-economic system that replaces the industrial paradigm.

\section{RESULTS}

The digital revolution is now well underway in all sectors of the world economy. Companies invest in new technologies and are engaged in innovation, and top management is committed to using digital solutions to break ahead and outperform competitors [2]. At present, the digital economy is actively developing and in the next few years it will be the most important engine for innovations, competitive ability and economic growth in the world. This is due to the fact that it makes public and commercial services available, ensures lower costs for the promotion of goods and products, reduces the time for making payments and opens up new sources of income.

One of the priority factors for the competitive ability and economic growth of Ukrainian enterprises in an integrated economy should be the practical use of science-based mechanisms for the development and implementation of scientific and technological innovations. This is due, on the one hand, to a significant breakthrough in the technological and informational spheres of the economy, and, on the other hand, to the market's need for innovative products and the orientation of enterprises towards creating new sources of competitive advantages. Moreover, statistics on the introduction of innovations in industry allow us to conclude 
that the share of enterprises using innovations has sharply decreased in recent years, and according to experts, it is less than one sixth of the total number of enterprises [3, 4].

Innovation in scientific research is usually understood as any change in technology, organization of production, products that differs from the existing practice at a given enterprise in an industry, country and is characterized by a high probability of a useful effect in a fairly short time period [5].

Despite the significant diversity of the aspectual composition of innovations (social, product, legal, organizational and managerial, economic, material and technological, technical and technological), the significant impact of each type of innovation on the management and production process of the enterprise, technical and technological innovation play the main role in ensuring expanded reproduction on a qualitatively new base. Having a direct impact on the aspectual composition of fixed and intangible assets, the applied technological processes, technical and technological innovations are an important element of modernization of the current performance of the enterprise and a condition for ensuring its competitive ability [6].

Digitalization issues for the innovative development of Ukrainian industry are the number one priority. They find a place in specifying the development strategies of the leading sectors of the national economy, especially export-oriented ones. They provide the flow of processes based on digital technology. There are more and more digital products that all provide digital, computing, telecommunication, and network devices. At the same time, the digital economy is increasingly seen as a set of social relations that are formed as a result of the use of electronic technologies, as well as technologies to ensure the analysis of large amounts of information to optimize the processes of forecasting the planning, production and consumption of science-intensive and high-tech products, as well as the level increase of economic development countries.

Despite the obvious benefits from the introduction of technological innovations in the production process in the context of structural changes in the global economy caused by its digitalization, domestic enterprises face a number of problems in their implementation.

In the study of innovative activity in the Ukrainian economy according to the CIS methodology, identified causes and factors affecting the level of innovative activity of enterprises and preventing the implementation of innovative activities for the period 2014 - 2017 attract attention. Thus, according to the results of the study, $82.2 \%$ of enterprises admit that there are no good reasons for the implementation of technological innovations, which is 7.45 due to the lack of good ideas or opportunities for innovation, as well as a $6 \%$ low demand for innovation in the market. At the same time, $17.8 \%$ of enterprise managers say that weighty factors hinder the possible implementation of technological innovations. To a large extent $(11.4 \%)$ this fact is due to the lack of financial resources within the enterprise; lack of loans or direct investments for the implementation of innovative activities $(6.1 \%) ; 5.8 \%$ of the reasons that prevent from the implementation of innovation are related to difficulties in obtaining state aid or subsidies for innovation [7].
In the theory of innovation management, there are many classifications of factors that affect the activity of innovative processes, ensuring or containing their development. Thus, based on the identification of factors constraining the activity of the development of innovative processes, barriers to the development of innovative activities of manufacturing enterprises are identified.

The systematization of research papers in the field of studying the drivers influencing the innovative activity of an enterprise made it possible to develop the following classification of factors impacting the effectiveness of innovative processes, as well as to substantiate the group of factors (barriers) that impede the development and implementation of technological innovations in the context of structural changes in the global economy caused by its digitalization ( fig. 1):

1. Financial and economic factors: deficit of own current assets for financing innovative activities, high cost of borrowed sources of financing for involving them in innovative projects, lack or insufficient state investments to carry out innovative activities; long payback period and low profitability of innovations, outdated equipment and technological processes, inefficient system of tax innovative benefits and subsidies.

2. Institutional and legal factors: the dominance of the current goals of the enterprise over long-term due to the instability of the external environment; ineffective legislation in the field of organization and protection of innovation, underdevelopment of innovation infrastructure, bureaucratic procedures and corruption.

3. Social factors: low qualification level of employees; the need for retraining of personnel working with innovations, the lack of staff motivation for the innovative development of the enterprise, the demographic gap in the perception of innovation.

4. Information and communication factors: lack of information about the markets for new technologies; the prevalence of vertical flows of information; ineffective information security system.

The presence of a significant number of barriers requires the development of an appropriate methodological approach for identifying them and influencing the performance of the enterprise itself, as the main condition for the implementation of innovative activities in the context of structural changes in the global economy caused by its digitalization. The development of a system for measuring the level of effectiveness of the implementation of technical and technological innovations is one of the necessary and essential conditions both for creating strategies for innovation development, and to identify barriers to the introduction of these innovations when implementing the appropriate strategy in the context of structural changes in the global economy caused by its digitalization.

The concept of the high-tech enterprises functioning in the implementation of digital technologies means:

- transformation of existing enterprises into digital ones by means of integrated automation and implementation of 
digital technologies in all areas of the organization;

- widespread introduction into practice of 3D-design technologies, mathematical modeling and advanced computer technologies;

- creation of a digital knowledge base of product samples for effective use as a scientific and technical reserve when upgrading existing and creating promising product samples;

- ensuring the compliance with the requirements for the protection of confidential data, information constituting trade secrets and information security;

- the development of a training system for specialists in the field of digital technology.

The basic digital technologies are "big data", artificial intelligence, blockchain, robotics, the above mentioned industrial Internet, unmanned aerial vehicles, as well as new technologies of virtual and augmented realities. Artificial intelligence is widely used in the creation of intelligent machines, for example, intelligent computer programs that allow intelligent systems to carry out cognitive functions associated with creative processes, which was previously considered the prerogative of only humans.

The widespread adoption of information technology at all stages of the life cycle of production enterprises determines the development of industries in general and each enterprise in particular. Full life cycle contracts have proven to be an effective tool for reducing suppliers' costs and, consequently, cost savings of budget. The digital economy will allow real-time monitoring and coordination of all stages of production and repair of products, from the conclusion of the contract to the delivery of products to the buyer.

However, in order to manage production and economic systems in the digital economy, the measurement system should, firstly, be as informative as possible and be based on real-life information support, and secondly, adequately reflect the structure of the selected groups of barriers (financial and economic, institutional and legal, social and information - communicative).

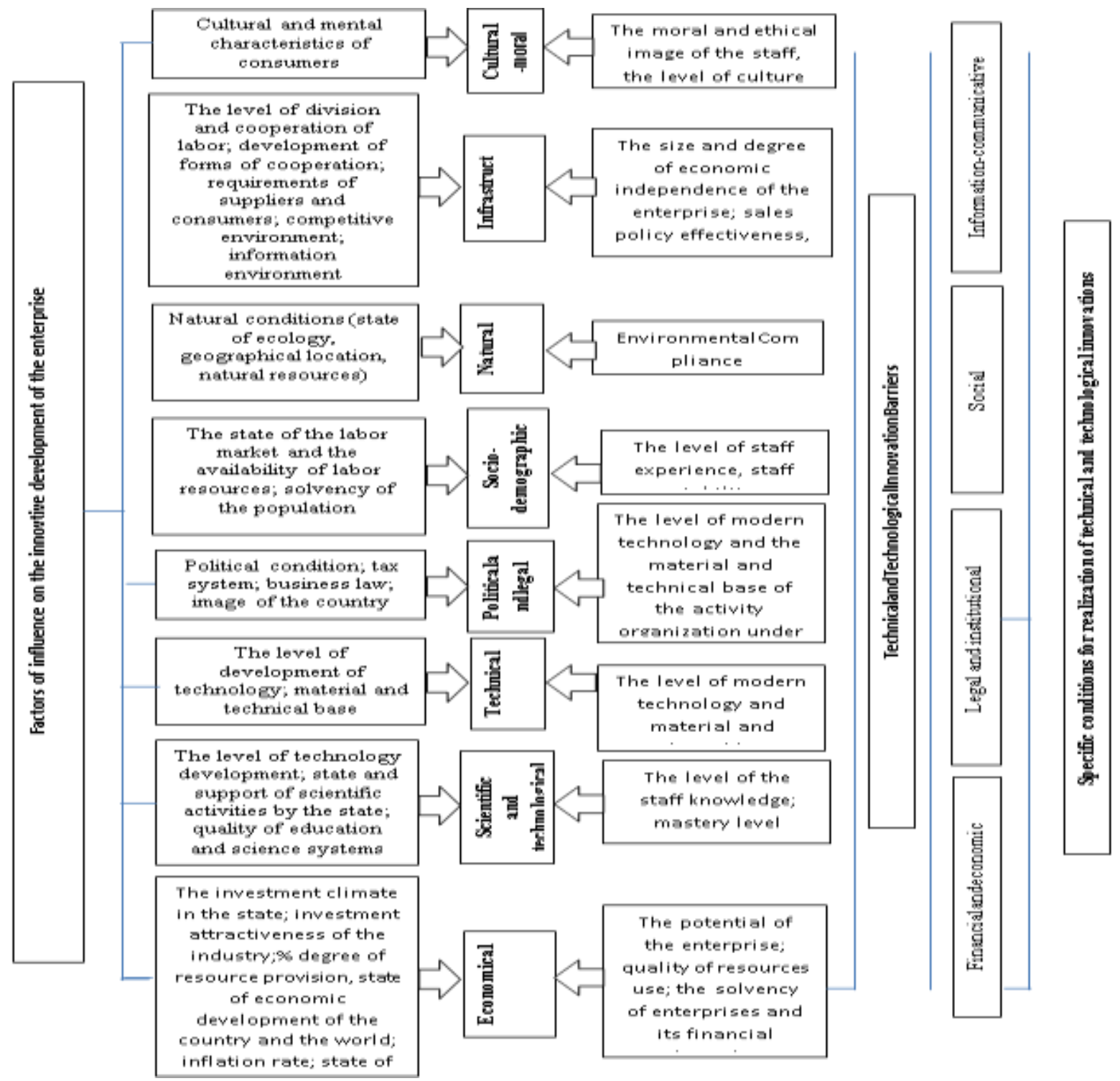

Fig. 1. Factors of influence on the innovative development of the enterprise in the context of structural changes in the global economy caused by its digitalization (developed by the author). 
A very important stage in the development of relevant indicators is the formation of the information space on which they are defined. First of all, it is about the content of the initial indicators and their indicators, which are able to assess the effectiveness of the implementation of technical and technological innovations in enterprises of the real sector of the economy, while they should be objective characteristics of the relevant influence factors and can be obtained on the basis of official statistical information.The definition of the integrated performance index for the introduction of technical and technological innovations in enterprises of the real sector of the economy in the context of structural changes in the world economy caused by its digitalization and the corresponding sub-indices in its structure is based on a four-level hierarchical model, i.e., the integrated performance indicator is a vector with sub-indices components by types of factors influence:

$$
\left\{I_{\text {LEE }}\right\}=\left\{I_{\text {FEF }} ; I_{\text {IIL }} ; I_{\text {SEF }} ; I_{\text {IKF }}\right\} \text { or }\left\{I_{\text {LEE }}\right\}=\left\{I_{i}\right\}(1)
$$

The developed hierarchical model allows you to build several types of sub-indices for a deeper analysis of the current level of effectiveness of the introduction of technical and technological innovations in enterprises of the real sector of the economy in the context of structural changes in the world economy caused by its digitalization, differentiated by hierarchy levels, i.e.:

- for certain types of influence factors in the whole enterprise, namely:

- $I_{F E F}$ - index of the influence of financial and economic factors on the effectiveness of the introduction of technical and technological innovations;

- IIL - index of the influence of institutional and legal factors on the effectiveness of the introduction of technical and technological innovations;

- $I_{S E F}$ - index of the influence of socio-economic factors on the effectiveness of the introduction of technical and technological innovations;

- $I_{I K F}$ - index of the influence of information and communication factors on the

effectiveness of the introduction of technical and technological innovations;

- for certain types of economic activity, taking into account all types of factors $\left(I_{j}\right)$;

- as a whole throughout the enterprise, i.e., a combination of both the four types of factors identified and the types of activities ( $I_{L E E}$ ).

The definition of the corresponding sub-indexes is based on the multidimensional average, which in the present study implements the multidimensional simple arithmetic average algorithm:

$$
l_{i}=\frac{\sum_{j=1}^{m} I_{i j}}{m}
$$

$$
l_{j}=\frac{\sum_{i=1}^{n} l_{i j}}{n}(3)
$$

where $\mathrm{i}$ is the number of the resource type;

$\mathrm{n}$ - is the number of types of factors that determine the level of effectiveness of the introduction of technical and technological innovations at the enterprise; $n$ is 4 ;

$\mathrm{j}$-is the number of the type of economic activity of the enterprise;

$\mathrm{m}$-is the number of types of economic activity, on the set of which the strategy of innovative development is implemented;

$I_{i j}$ - is sub-index of effectiveness of the ith- type of factor when introducing technical and technological innovations of the $\mathrm{j}$ type of economic activity.

Each sub-index of influence factors in the implementation of technical and technological innovations is calculated on the basis of internal indicators, i.e.:

$$
l_{i j}=\frac{\sum_{k=1}\left|l_{j j}\right|}{\left.I_{i} \mid l_{j}\right)},
$$

where $z_{i j k}$ - is the normalized value of internal indicators of $\mathrm{i}$-th-type of factor and $\mathrm{j}$-th-type of activity;

$k$-is the number of $i$-th type of factor sub-system indicator or $\mathrm{j}$-thtype of economic activity;

$l_{i}$ - the number of indicators of the $\mathrm{i}$-th factors subsystem, and - respectively, $l_{j}$ - of that type of economic activity.

The integrated performance index for the introduction of technological innovations in enterprises of the real sector of the economy in the context of structural changes in the global economy caused by its digitalization can also be represented as follows:

$$
I_{L E E}=\frac{\sum_{i=1}^{n} \sum_{j=1}^{m} l_{i j}}{n m}
$$

More generally, the algorithm for determining the presented indicators, in particular, the numerators of the corresponding ratios, is an additive functional model, which makes it possible to determine the effect of individual internal components on the relative change in the corresponding sub-indices or the integrated performance index for the implementation of technical and technological innovations in whole based on the proportional division method.

In particular, for certain types of sub-indexes, the following relations are used:

$$
\Delta I_{i /(j) \text {,inf. }}=\frac{\Delta I_{i, \text { inf. }}}{\Delta I_{i_{1}}+\Delta I_{i_{2}}+\ldots+\Delta I_{i_{m}}} \Delta I_{i j} ;
$$




$$
\begin{aligned}
& \Delta I_{j /(i) \text {,inf. }}=\frac{\Delta I_{j, \text { inf. }}}{\Delta I_{j_{1}}+\Delta I_{j_{2}}+\ldots+\Delta I_{j_{m}}} \Delta I_{i j} ; \\
& \Delta I_{У P \Pi /(i)}=\frac{\Delta I_{У P \Pi, \text { отн. }}}{\Delta I_{1}+\Delta I_{2}+\ldots+\Delta I_{n}} \Delta I_{i} ; \\
& \Delta I_{L E E /(j)}=\frac{\Delta I_{L E E, \text { inf. }}}{\Delta I_{1}+\Delta I_{2}+\ldots+\Delta I_{m}} \Delta I_{j} ;
\end{aligned}
$$

where $\Delta I_{i /(j), \text { inf. }}$ - is the relative influence of $\mathrm{j}$-thtype of activity on the relative change in the sub-index of the i-th factor in ensuring the effectiveness of the introduction of technical and technological innovations;

- $\Delta I_{j /(i), \text { inf. }}$ - is the relative influence of the i-th type factor on the relative influence of the sub-index of $j$-thtype of economic activity;

- $\Delta I_{L E E /(i)}$ or $-\Delta I_{L E E /(j)}$ - is a relative change in the integral indicator (integrated index) of the effectiveness of the introduction of technical and technological innovations under the influence, respectively, of the i-th type of factor or j-thtype of economic activity.

This approach provides an opportunity to accurately determine the main factors (and the degree of their impact) that affect the effectiveness of the introduction of technical and technological innovations in enterprises of the real sector of the economy in the context of structural changes in the world economy caused by its digitalization and justify management decisions in the structure of the corresponding management mechanism.

The practical implementation of the methodology for assessing the effectiveness of the processes of activating an innovative economy in the context of structural changes in the global economy caused by its digitalization is based on statistical data on the value of relevant indicators (financial,

\begin{tabular}{|c|c|c|c|c|c|c|c|c|c|c|}
\hline \multirow{3}{*}{ Year } & $\left(I_{L E E}\right)$ & \multicolumn{9}{|c|}{ Sub-indexes of enterprise development factors, $\left(l_{i}\right)$ including: } \\
\hline & \multirow[t]{2}{*}{ level } & \multirow{2}{*}{$\begin{array}{c}\text { rate of } \\
\text { change in } \% \\
\text { to the previous } \\
\text { period }\end{array}$} & \multicolumn{2}{|c|}{ socio-economic } & \multicolumn{2}{|c|}{ 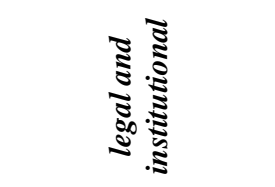 } & \multicolumn{2}{|c|}{$\begin{array}{l}\text { financial and } \\
\text { economic }\end{array}$} & \multicolumn{2}{|c|}{$\begin{array}{l}\text { technical and } \\
\text { technological }\end{array}$} \\
\hline & & & level & $\begin{array}{c}\text { rate of } \\
\text { change } \\
\text { in\% }\end{array}$ & level & $\begin{array}{c}\text { rate of } \\
\text { change } \\
\text { in } \%\end{array}$ & level & $\begin{array}{c}\text { rate of } \\
\text { change } \\
\text { in } \%\end{array}$ & level & $\begin{array}{c}\text { rate of } \\
\text { change } \\
\text { in\% }\end{array}$ \\
\hline 2014 & 0,533 & 100 & 0,609 & 100 & 0,666 & 100 & 0,503 & 100 & 0,355 & 100 \\
\hline 2015 & 0,532 & 99,8 & 0,567 & 93,1 & 0,669 & 100,5 & 0,528 & 105 & 0,368 & 103,7 \\
\hline 2016 & 0,565 & 106,2 & 0,587 & 103,5 & 0,692 & 103,4 & 0,559 & 105,9 & 0,422 & 114,7 \\
\hline 2017 & 0,574 & 101,8 & 0,592 & 100,9 & 0,722 & 104,3 & 0,469 & 83,9 & 0,513 & 121,6 \\
\hline $\begin{array}{c}\text { On } \\
\text { averag } \\
\text { e, } \%\end{array}$ & 0,551 & 100,8 & 0,589 & 99,7 & 0,687 & 100,9 & 0,515 & 99,2 & 0,414 & 104,2 \\
\hline
\end{tabular}

\section{Table 1}

Integral performance indices of innovative processes of enterprises in Ukraine $\left(I_{L E E}\right)$

Source: data obtained on the basis of the author's calculations according to official materials of the State Statistics Service of Ukraine [8]. economic,

socio-economic,

technical, technological,institutional and legal factors) for a certain period of time. This involves the use of official materials of the State Statistics Service of Ukraine, namely: structural statistics indicators for business entities, indicators of cost, availability and condition of fixed assets of enterprises of Ukraine by type of economic activity, capital investment by type and source of formation, indices of industrial products produced and sold and other technical and economic indicators of industrial enterprises [8].

\section{DISCUSSION}

Analysis of the dynamics of integral indicators of the effectiveness of the intensifying processes of innovative activity of enterprises in the agro-industrial complex, fuel and energy complex, chemical, metallurgical, food industry, and mechanical engineering of Ukraine. (table. 1) indicates that for the analyzed period from 2014 to 2017 there were no significant changes in the level of development of innovative processes.

If in 2011 the level of the integral indicator was 0.533 , then in 2017 it increased only by 0.041 coefficient points or $7.7 \%$, i.e. annually, on average, the level of innovation activity increased by only $0.8 \%$. It should be noted that the dynamics of sub-indexes by factors of activation of innovative development does not have such a definite tendency. In particular, the sub-index of social and labor factors, after a significant decrease during the financial crisis (by $-6.9 \%$ ), did not reach the level of 2011 by 2017 , which caused its annual decrease by an average of $0.3 \%$. The pattern of changes in the sub-index of financial and economic factors up to 2017 tended to increase, while at the same time as of 2017 the level of the sub-index decreased by 0.09 coefficient points or $16.9 \%$ compared to the previous year, and on average by a six-year period of decline was $0.8 \%$. 
At the same time, there was a positive trend in the sub-index of technical and technological factors, while the highest growth rate just occurred in 2017 compared to the previous year. On average, annually for 2011 - 2017 the sub-index of activation of technical and technological factors increased by $4.2 \%$. It should be noted that the sub-index of the efficiency of using technical and technological factors for the development of innovative activity in enterprises of the real economy sector, despite fairly high growth rates, remained at a relatively low level.

Factor analysis based on the method of proportional division, i.e. by ratios $(2-3)$ and presented in table 2 , makes it possible to determine the role and importance of each type of factor in ensuring the activation of innovative processes, in terms of the effectiveness of the introduction of technical and technological innovations at enterprises in Ukraine.
Almost the entire increase over the analyzed six-year period of the integrated performance index for introducing technical and technological innovations $(7.7 \%)$ was provided by an increase in the efficiency of using technical and technological factors $(+7.49)$, as well as institutional and legal factors $(+2.65)$.

At the same time, socio-economic and financial-economic factors are the main disincentive to the ensuring the effectiveness of the introduction of technical and technological innovations. It should be noted that the greatest decrease in the effectiveness of introducing technical and technological innovations by financial and economic factors occurred in 2017 compared to the previous year, but the maximum decrease in the sub-index of socio-economic factors was in 2011, as a result of the financial crisis.

Table 2

Analysis of the influence factors on the effectiveness change of innovative processes of enterprises in Ukraine

\begin{tabular}{|c|c|c|c|c|c|c|}
\hline \multirow[b]{2}{*}{ Year } & \multicolumn{2}{|r|}{$\left(I_{L E E}\right)$} & \multicolumn{4}{|c|}{$\begin{array}{c}\text { The relative influence of development factors on the integral index } \\
\text { change, } \%\end{array}$} \\
\hline & level & $\begin{array}{c}\text { rate of } \\
\text { change in\% } \\
\text { to the } \\
\text { previous period }\end{array}$ & $\begin{array}{l}\text { socio-economi } \\
\quad c\end{array}$ & $\begin{array}{r}\text { legal and } \\
\text { institutional }\end{array}$ & $\begin{array}{l}\text { financial and } \\
\text { economic }\end{array}$ & $\begin{array}{c}\text { technical } \\
\text { and } \\
\text { technologica } \\
l\end{array}$ \\
\hline 2015 & 0,532 & $-0,192$ & $-7,92$ & 0,633 & 4,72 & 2,375 \\
\hline 2016 & 0,565 & 6,2 & 0,94 & 1,1 & 1,52 & 2,64 \\
\hline 2017 & 0,574 & 1,6 & 0,25 & 1,364 & $-4,144$ & 4,13 \\
\hline $\begin{array}{l}2017 \text { co } \\
\text { mpared } \\
\text { to } 2014\end{array}$ & - & 7,7 & $-0,8$ & 2,65 & $-1,64$ & 7,49 \\
\hline
\end{tabular}

Source: data obtained on the basis of the author's calculations according to official materials of the State Statistics Service of Ukraine [8].

The nature, patterns and trends of sub-indices, the ratio of their levels show a sufficient degree of unevenness of their change, which indicates a rather low level of efficiency of innovative activity of enterprises of the real sector of the economy in modern economic conditions in Ukraine.

\section{CONCLUSION}

Now we are only at the threshold of understanding the transformation of the economy through the introduction of digital technologies. But today there are new requirements for communications, computing power, information systems and services. The requirements for employees in terms of their digital competencies and digital skills are changing.

The identified factors restraining the innovative activity of an enterprise in the real sector of the economy in introducing technical and technological innovations into the production process under the conditions of structural changes in the world economy caused by its digitalization allow us to determine the main priorities for increasing the enterprise's competitive ability and develop a strategy for its innovative development.

Since the Ukrainian economy requires the focused strategy aimed at modernization, ensuring competitiveness, creating a favorable investment climate and building a real basis for the European integration of the state, there is a need for a fundamentally new analysis of the features of socio-economic development of Ukraine at the present stage, identifying the main problems that arise ways of further socio-economic progress and environmental safety of Ukraine in conditions of structural changes in the world economy caused by its digitalization.

In this regard, the presented analysis of the influence of individual internal indicators on the change in the level of resource sustainability allows us to systematize and determine the direction of their influence, to identify reserves for increasing sustainability for each type of activity. In addition, the specification of indicators for each type of economic activity provides clarification of the economic management mechanism in ensuring the growth of resource sustainability.

As the main directions of the activation and development of technical and technological innovations of enterprises in the real sector of the economy in the context of structural changes in the global economy caused by its digitalization we should consider: effective state support for innovative programs for the development of production enterprises (especially export-oriented), attraction of venture capital, increasing the financial stability of the enterprise, 
increasing the flexibility of production processes, using advanced methods of organizing production, labor and enterprise management.

\section{REFERENCES}

1. Boiarynova K. O. (2017). Kontseptual'ni aspekty vyznachannia hotovnosti promyslovoho pidpryiemstva do innovatsij iak dosvidu innovatsijnoi diial'nosti [Conceptual aspects of determining the readiness of an industrial enterprise for innovations as the experience of innovation activity]. Investytsii: praktyka ta dosvid Investments: Practice and Experience, 13, 18-21 [in Ukrainian].

2. Heiets V. M., Semynozhenko, V. P. (2006). Innovatsiini perspektyvy Ukrainy [Innovative perspectives of Ukraine] Kharkiv: Konstanta[in Ukrainian]

3. Potudanskaja V. F., Cygankova I. V., Novikova T. V. (2013). Problema funkcionirovanija socio-tehnologicheskih sistem $\mathrm{v}$ uslovijah razvitija innovacionnyh tehnologij [The problem of functioning of socio-technological systems in the conditions of development of innovative technologies]. Vestnik INZHJEKONa-INESECON's Bulletin, 7(50), 94-99 [in Russian].

4. Semjonov V. M., Kuchina E. V. (2015). Razvitie tehniko-tehnologicheskih innovacij kak osnova obespechenija konkurentosposobnosti promyshlennyh predprijatij [Development of technical and technological innovations as a basis for ensuring the competitiveness of industrial enterprises]. Vestnik Ural'skogo finansovogo universiteta. - Bulletin of Ural Financial University, 5, 67-77 [in Russian].

5. Amosha O. I., Antoniuk V. P., Zemliankin A. I. et al (2007). Aktyvizatsiia innovatsijnoi diial'nosti: orhanizatsijno-pravove ta sotsial'no-ekonomichne zabezpechennia [The activation of innovation activity: organizational-legal and socio-economic support]. NAN Ukrainy, Instytut ekonomiky promyslovosti. Donetsk [in Ukrainian].

6. Varnalij Z. S., Harmashova O. P (2015). Konkurentospromozhnist' natsional'noi ekonomiky: problemy ta priorytety innovatsijnoho zabezpechennia [The competitiveness of the national economy: problems and priorities of innovative provision]. Kiev: ZnanniaUkrainy[in Ukrainian].

7. Bakunov O. O., Roshka M. S. (2017). Kontseptual'nyj pidkhid do upravlinnia innovatsijnym rozvytkom pidpryiemstva [Conceptual approach to management of innovation development of an enterprise]. Biuleten' Mizhnarodnoho Nobelivs'koho ekonomichnoho forumuBulletin of the International Nobel Economic Forum, Vol. 1, 1(9), 22-29 [in Ukrainian].

8. Ofitsijnyj sajt Derzhavnoi sluzhby statystyky Ukrainy [Official website of the State Statistics Service of Ukraine]. Retrieved from http://www.ukrstat.gov.ua.

9. Schumpeter J. (1992). Teorijaj ekonomicheskogo razvitija [The Theory of Economic Development]. (V. S. Avtonomov et al., Trans.). Moscow: Progress [in Russian].

10. Gokhberg L. (2016). From equality to diversity: classifying Russian universities in a performance oriented system. Technological Forecasting and Social Change, 103, 228-239.

11. Toffler A. (1990) Power shift: knowledge, wealth, and violence at the edge of the 21 st century. New York: Bantam books.

12. Reznik N.P., Demyan Y.Y., Tokar Y.I., Gupta S.K., Ostapchuk A.D. (2019): Mechanism of investment maintenance for the sustainable development of the agricultural sphere. International Journal of Engineering and Advanced Technology, 8 (11),pp. 112-116 